Prepared in cooperation with the Federal Emergency Management Agency and the U.S. Army Corps of Engineers

\title{
Peak Streamflow and Stages at Selected Streamgages on the Arkansas River in Oklahoma and Arkansas, May to June 2019
}

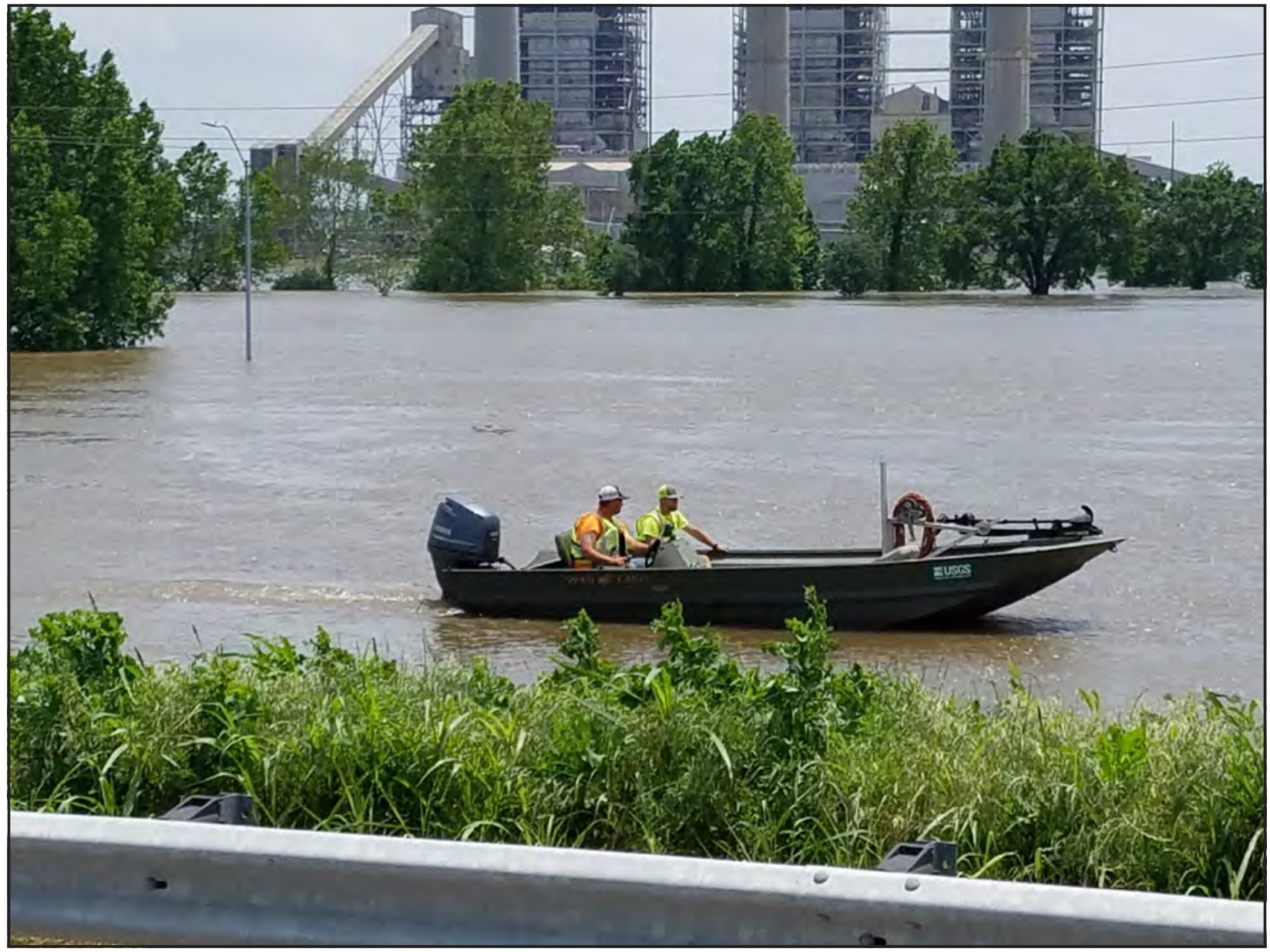

Open-File Report 2019-1129 
Cover. Photograph showing two U.S. Geological Survey hydrographers navigating floodwaters downstream from the U.S. Highway 62 bridge on the Arkansas River near Muskogee, Oklahoma, May 23, 2019. Photograph by Scott Strong, U.S. Geological Survey. 


\section{Peak Streamflow and Stages at Selected Streamgages on the Arkansas River in Oklahoma and Arkansas, May to June 2019}

By Jason M. Lewis and Adam R. Trevisan

Prepared in cooperation with the Federal Emergency Management Agency and the U.S. Army Corps of Engineers

Open-File Report 2019-1129 


\title{
U.S. Department of the Interior \\ DAVID BERNHARDT, Secretary
}

\author{
U.S. Geological Survey \\ James F. Reilly II, Director
}

U.S. Geological Survey, Reston, Virginia: 2019

For more information on the USGS - the Federal source for science about the Earth, its natural and living resources, natural hazards, and the environment—visit https://www.usgs.gov or call 1-888-ASK-USGS.

For an overview of USGS information products, including maps, imagery, and publications, visit https://store.usgs.gov/.

Any use of trade, firm, or product names is for descriptive purposes only and does not imply endorsement by the U.S. Government.

Although this information product, for the most part, is in the public domain, it also may contain copyrighted materials as noted in the text. Permission to reproduce copyrighted items must be secured from the copyright owner.

Suggested citation:

Lewis, J.M., and Trevisan, A.R., 2019, Peak streamflow and stages at selected streamgages on the Arkansas River in Oklahoma and Arkansas, May to June 2019: U.S. Geological Survey Open-File Report 2019-1129, 10 p., https://doi.org/10.3133/ofr20191129.

ISSN 2331-1258 (online) 


\section{Contents}

Abstract

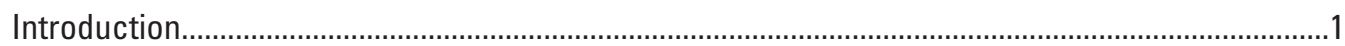

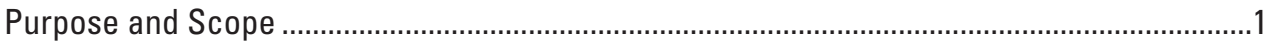

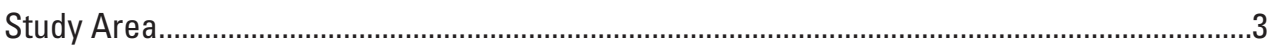

General Weather Conditions and Rainfall During May 2019 .......................................................

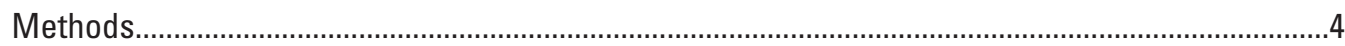

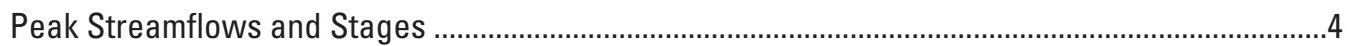

Flood Exceedance Probabilities of Peak Streamflows ....................................................................

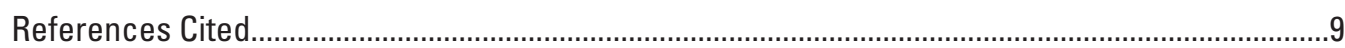

\section{Figures}

1. Map showing the location of selected U.S. Geological Survey streamgages along the Arkansas River and the total rainfall accumulation that occurred during May 2019

2. Photograph looking downstream from U.S. Highway 62 bridge at the widespread flooding and backwater conditions on the Arkansas River near Muskogee, Oklahoma, May 31, 2019

3. Map showing the Arkansas River Basin, which includes the McClellan-Kerr Arkansas River Navigation System

4. Rating curve for the U.S. Geological Survey streamgage 07165570, Arkansas River near Haskell, Oklahoma.

5. Photograph showing a direct streamflow measurement from the 11th Street bridge, looking downstream on the Arkansas River at Tulsa, Oklahoma, near U.S. Geological Survey streamgage 07164500 .

6. Flood-frequency curve for the annual peak streamflows at U.S. Geological Survey streamgage 07194500, Arkansas River near Muskogee, Oklahoma

\section{Tables}

1. Site information for selected streamgages along the Arkansas River and peak streamflow values for the May to June 2019 flood event

2. Selected recurrence intervals and the associated annual exceedance probabilities

3. Streamgage information related to calculation of annual exceedance probability for the May to June 2019 flood event along the Arkansas River in Oklahoma and Arkansas. 


\section{Conversion Factors}

Inch/Pound to SI

\begin{tabular}{lcl}
\hline \multicolumn{1}{c}{ Multiply } & By & \multicolumn{1}{c}{ To obtain } \\
\hline inch (in.) & Length & \\
inch (in.) & 2.54 & centimeter $(\mathrm{cm})$ \\
foot (ft) & 25.4 & millimeter $(\mathrm{mm})$ \\
mile (mi) & 0.3048 & meter $(\mathrm{m})$ \\
\hline & 1.609 & kilometer $(\mathrm{km})$ \\
\hline square mile $\left(\mathrm{mi}^{2}\right)$ & Area & hectare $(\mathrm{ha})$ \\
square mile $\left(\mathrm{mi}^{2}\right)$ & 259.0 & square kilometer $\left(\mathrm{km}{ }^{2}\right)$ \\
\hline & 2.590 & \\
\hline foot per second $(\mathrm{ft} / \mathrm{s})$ & Flow rate & meter per second $(\mathrm{m} / \mathrm{s})$ \\
cubic foot per second $(\mathrm{ft} / \mathrm{s})$ & 0.3048 & cubic meter per second $\left(\mathrm{m}^{3} / \mathrm{s}\right)$ \\
\hline
\end{tabular}

\section{Datum}

Horizontal coordinate information is referenced to the North American Datum of 1983 (NAD 83).

\section{Abbreviations}
AEP annual exceedance probability
FEMA Federal Emergency Management Agency
NOAA National Oceanic and Atmospheric Administration
USACE U.S. Army Corps of Engineers
USGS U.S. Geological Survey 


\title{
Peak Streamflow and Stages at Selected Streamgages on the Arkansas River in Oklahoma and Arkansas, May to June 2019
}

\author{
By Jason M. Lewis and Adam R. Trevisan
}

\begin{abstract}
As much as 22 inches of rain fell in Oklahoma in May 2019, resulting in historic flooding along the Arkansas River in Oklahoma and Arkansas. The flooding along the Arkansas River and its tributaries that began in May continued into June 2019. Peaks of record were measured at 12 U.S. Geological Survey (USGS) streamgages on various streams in eastern and northeastern Oklahoma. This report documents the peak streamflows and stages for seven selected streamgages along the Arkansas River in Oklahoma and Arkansas. Most of the flood peaks occurred from May 26 to June 4, 2019. The historic flooding caused homes to fall into the river as a result of bank erosion, forced some towns to be evacuated, and resulted in the highest flood depths in Tulsa, Oklahoma, since 1986. Along the Arkansas River, peak streamflows were recorded at six of the seven selected USGS streamgages, with the seventh streamgage on the Arkansas River having the second highest peak of record at that site since regulation began.
\end{abstract}

\section{Introduction}

Heavy rainfall resulted in major flooding across parts of Oklahoma and Arkansas during May 2019, with some areas receiving more than 22 inches of rainfall for the month (Mesonet, 2019). Most of the rain fell in a 36-hour period during May 19-May 21 in a large swath across northeastern Oklahoma and southeastern Kansas (fig. 1). Most of the flood peaks occurred from May 26 to June 4, 2019. Along the Arkansas River, at least three levees were breached between Fort Smith and Little Rock, Arkansas, and an additional five levees suffered substantial damage (U.S. Army Corps of Engineers, Little Rock District, written commun., 2019). Maps of floods and high-flow conditions can be accessed at the U.S. Geological Survey (USGS) WaterWatch website (https://waterwatch.usgs.gov/; USGS, 2019a).

The Arkansas River Basin has flooded, sometimes catastrophically, in the past. Examples include the 1986 flood on the Arkansas River, which killed 1 person and caused 1,800 homes and business to be inundated (Jackson and Pittman, 2019).
Flooding in the reach of the Arkansas River near the city of Tulsa, Oklahoma, is usually caused by large amounts of rain and large releases from the upstream reservoirs. South of Tulsa, the Arkansas River reaches flatter topography, where the "backwater" effect of numerous tributaries dumping water into the lower gradient Arkansas River results in the slower movement of floodwaters and increased flood heights (fig. 2).

The historic flooding in 2019 caused homes to fall into the river as a result of bank erosion, forced some towns to be evacuated, and resulted in the highest flood peaks in Tulsa since 1986 (PBS News Hour, 2019; Stanglin and Hughes, 2019). Several USGS streamgages along the Arkansas River recorded new peaks of record. As a result of the magnitude of the Arkansas River flooding, the USGS, in cooperation with the Federal Emergency Management Agency (FEMA) and the U.S. Army Corps of Engineers (USACE), assessed the meteorological and hydrological conditions prior to and during the flood and determined flood peak gage heights, streamflows, and flood exceedance probabilities at USGS and USACE streamgages.

The USGS collects and disseminates streamflow data for more than 8,000 streamgages nationwide (USGS, 2019b). In Oklahoma and Arkansas, the USGS operates 290 streamgages in cooperation with numerous local, State, and Federal agencies. Other agencies in Oklahoma and Arkansas, such as the USACE, also operate streamgages. Streamflow data collection serves a variety of purposes including flood monitoring. Leading up to and during flooding events, streamflow data are vital for flood warning, forecasting, and emergency management. Long-term systematic streamflow data are used to help mitigate the damage caused by floods in the design or repair of infrastructure (for example, roads, bridges, reservoirs, and pipelines), houses, and buildings (Congressional Research Service, 2019).

\section{Purpose and Scope}

The purpose of this report is to document the peak streamflows and stages for selected streamgages along the Arkansas River in Oklahoma and Arkansas that recorded the MayJune 2019 flood event. This includes both USGS and USACE streamgages. The 2019 flood peak flows are placed into context by ranking the 2019 data with the annual peak flood data for the regulated period of record at each streamgage. 


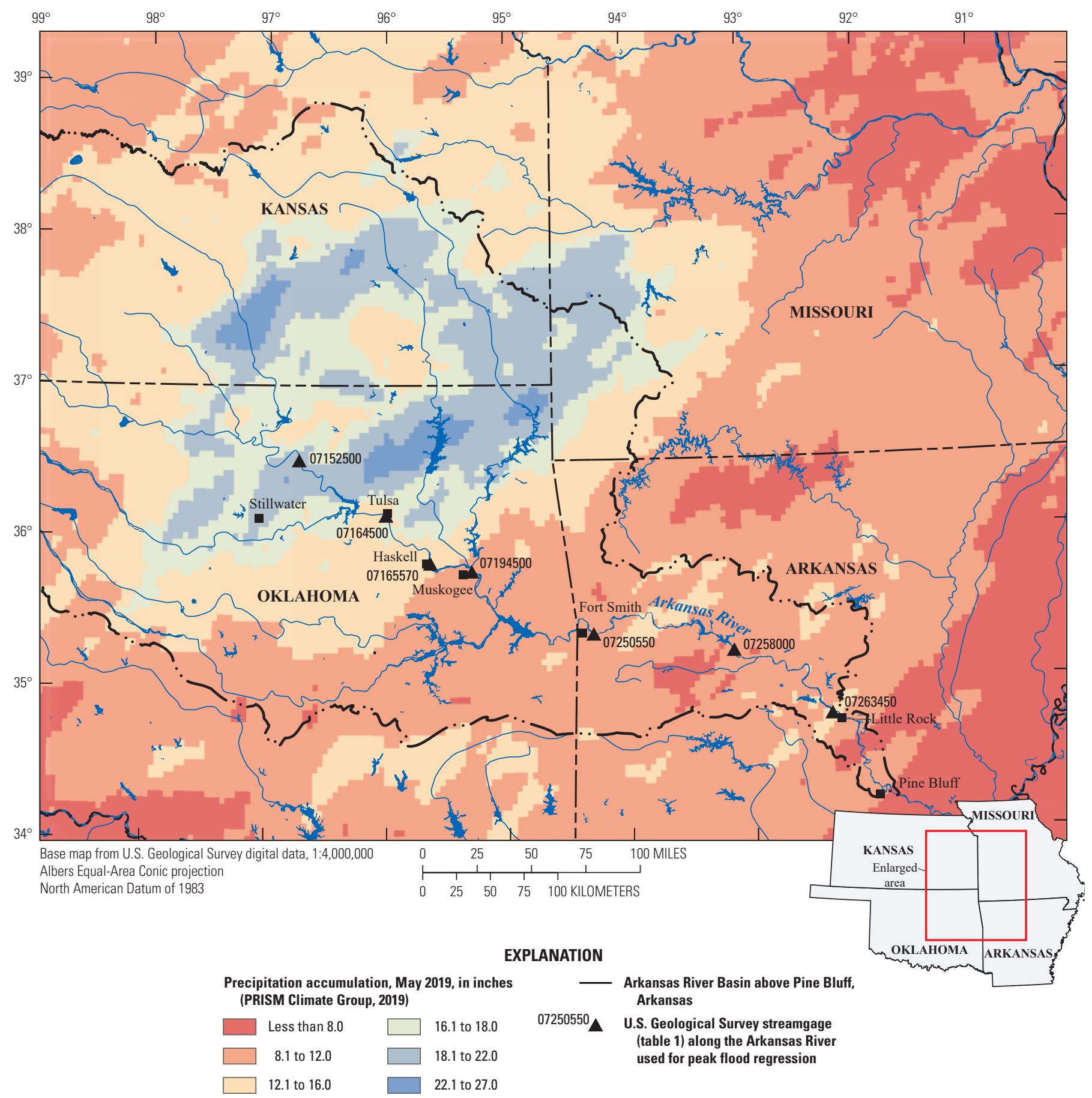

Figure 1. Location of selected U.S. Geological Survey streamgages along the Arkansas River and the total rainfall accumulation that occurred during May 2019. 


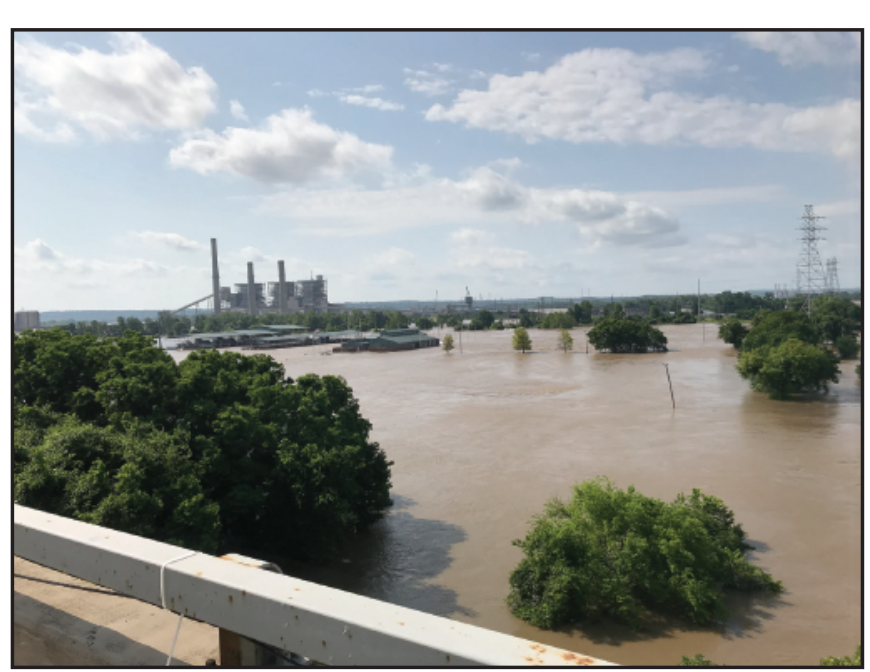

Figure 2. Looking downstream from U.S. Highway 62 bridge at the widespread flooding and backwater conditions on the Arkansas River near Muskogee, Oklahoma, May 31, 2019.

\section{Study Area}

The streamflow data (peak stage and streamflow) documented in this report were obtained from streamgages in the Arkansas River Basin, which drains large parts of Colorado, Kansas, Oklahoma, and Arkansas. The Arkansas River Basin has headwater streams along the eastern slope of the Rocky Mountains in Colorado; the Arkansas River crosses eastern Colorado and a large part of Kansas before continuing in an easterly to southeasterly direction through Oklahoma and Arkansas (fig. 3).

Land-use types in the study area include forest and woodlands, grass and rangelands, and urban (National Agricultural Statistics Service, 2016). Some parts of the Arkansas River in the study area are dredged for sand and gravel (USACE, 2010). The McClellan-Kerr Arkansas River Navigation System is an important infrastructure feature in the study area that facilitates interstate barge traffic; it starts at the Port of Catoosa in Catoosa, Okla. The McClellan-Kerr Arkansas River Navigation System follows the Verdigris River downstream from Catoosa to the confluence of the Verdigris and Arkansas Rivers near Muskogee, Okla., then follows the Arkansas River downstream through eastern Oklahoma and Arkansas, terminating at the confluence of the Arkansas and Mississippi Rivers (USACE, 2019).

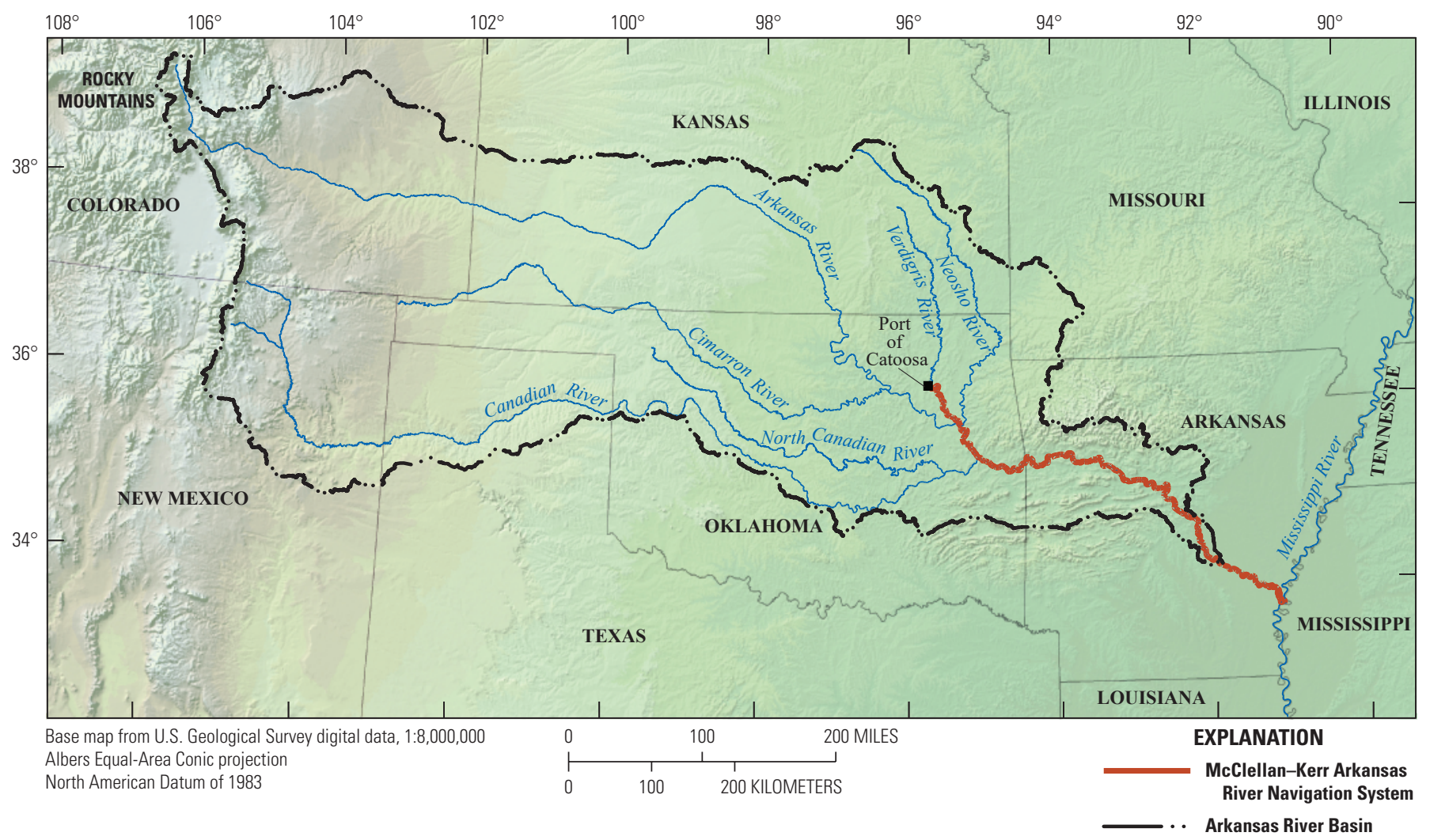

Figure 3. The Arkansas River Basin, which includes the McClellan-Kerr Arkansas River Navigation System. 
Peak Streamflow and Stages at Selected Streamgages on the Arkansas River in Oklahoma and Arkansas

\section{General Weather Conditions and Rainfall During May 2019}

In late May 2019, changes in the jet stream caused wind patterns to shift, drawing warm, moist air masses northward from the Gulf of Mexico. These warm, moist air masses combined with cooler-than-average air masses throughout Oklahoma and Kansas to produce historic rainfall for the month (National Oceanic and Atmospheric Administration [NOAA], 2019a). This pattern of repeated heavy rain culminated in an extreme rainfall event over a 24-hour period on May 21, 2019, when more than 6 inches of rain fell in parts of Tulsa and Stillwater, Okla. (NOAA, 2019b). After rains saturated much of Oklahoma and Kansas in the early part of the month, the additional heavy rainfall on May 21 spurred flooding along much of the Arkansas River. Smaller rainfall events following May 21 kept streams in flood stage through the end of May and early June (NOAA, 2019c). By the end of May 2019, parts of Oklahoma had received more than 25 inches of rain for the month (PRISM Climate Group, 2019). May rainfall totals were the highest on record for Kansas and Missouri, the second highest for Oklahoma, and the ninth highest for Arkansas, producing rainfall anomalies above the means of 6.66 inches, 5.65 inches, 6.78 inches, and 4.11 inches, respectively (NOAA, 2019c).

\section{Methods}

In this report, the term streamflow data refers to stage and volumetric streamflow (streamflow). Streamflow data were collected either systematically at streamgages or from periodic/intermittent field observations of streamflow at locations where no streamgage is present.

USGS streamgages operate autonomously by collecting data at set frequencies (typically either 15 or 30 minutes) dependent on basin size and concomitant flashiness of the stream. The typical streamgage automatically records stage data. Stage data are collected by using a variety of methods (float, submersible pressure transducer, nonsubmersible pressure transducer, or noncontact radar). Stage at each USGS streamgage was recorded every 15 minutes and transmitted hourly by the Geostationary Operational Environmental Satellite transmitter to the USGS National Water Information System database (USGS, 2019b).

Although stage data are important, streamflow data are often more important for such purposes as streamflow forecasting, water-quality loading, flood-frequency analysis, and flood-mitigation planning. Derivation of streamflow from stage data at a streamgage requires periodic measurements of streamflow for the construction of a relation that will convert the stage data to streamflow data. In most cases, the relation is a simple stage-streamflow rating curve (rating curve) (fig. 4). USGS personnel make onsite direct measurements of stream velocity and stream depth that are used to create the rating curve (fig. 5; Turnipseed and Sauer, 2010). After construction of the rating curve, continued periodic measurements of streamflow are required at various gage heights to calibrate the rating curve. The rating curve for the Arkansas River near Haskell, Okla. (07165570) streamgage was updated and extended based on data from the historic May 2019 streamflow (fig. 4). The rating curve allows for the determination of streamflow from the stage data when USGS personnel are not physically present at the streamgage to make a streamflow measurement.

In addition to the USGS, the USACE also collects streamflow data in the study area. Data collected by the USACE were obtained by using methods and standards similar to those used by USGS (USACE, Little Rock District, written commun., 2019). Any questions regarding methods of data collection for non-USGS data should be referred to the collecting agency. The USACE provided gage height records for the following sites: Arkansas River at James W. Trimble L\&D near Van Buren, Arkansas (07250550), Arkansas River at Dardanelle, Arkansas (07258000), and Arkansas River at Murray Dam near Little Rock, Arkansas (07263450) (USGS, 2019b). The USGS quality assured these data and determined a maximum peak stage and streamflow for each site for the flood event of 2019.

\section{Peak Streamflows and Stages}

Peaks of record were measured at 12 USGS streamgages on various streams in eastern and northeastern Oklahoma (USGS, 2019a). Peak streamflow and stage during the May to June 2019 floods for seven streamgages on the Arkansas River are provided (table 1; fig. 1). The streamgages included in table 1 were chosen because (1) the 2019 peak streamflow for that location ranked first or second among all peak flows at that station for the period of record, (2) the site was a periodic/intermittent location where the peak streamflow was determined, or (3) the USACE determined this to be a site of interest. The data in table 1 are from both the USGS and USACE.

The peak stage and streamflow are not always coincident in time for the locations in this report, particularly for lower gradient sinuous streams and rivers characterized by complicated hydraulics that only form in low-gradient environments (Holmes and others, 2013).

Most of the flood peaks were recorded near the end of May 2019, with flood peaks occurring later with distance downstream. One exception was USGS streamgage Arkansas River near Muskogee, Okla. (07194500) (fig. 1) where the flood peaked earlier than at the upstream Tulsa (07164500) and Haskell (07165570) streamgages because of inflow from the Neosho and Verdigris Rivers. 


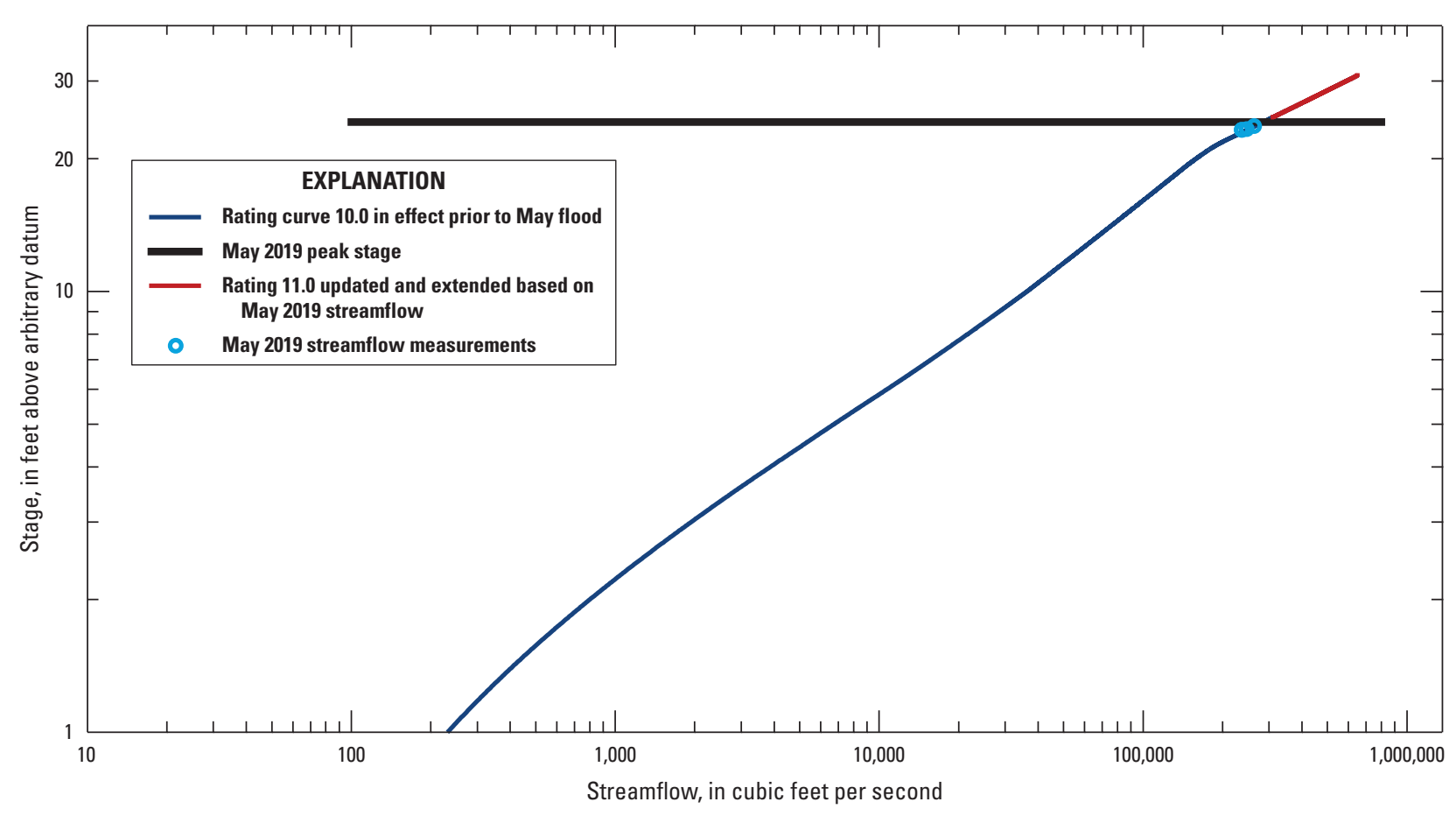

Figure 4. Rating curve for the U.S. Geological Survey streamgage 07165570, Arkansas River near Haskell, Oklahoma.

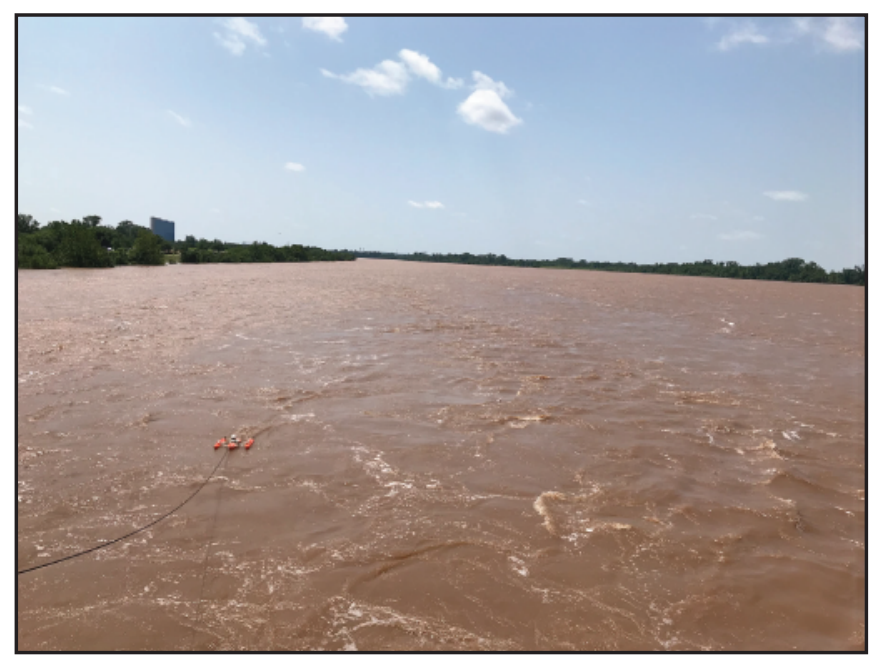

Figure 5. A direct streamflow measurement from the 11th Street bridge, looking downstream on the Arkansas River at Tulsa, Oklahoma, near U.S. Geological Survey streamgage 07164500.

\section{Flood Exceedance Probabilities of Peak Streamflows}

After a flood event, personnel from different agencies and groups commonly need to know the expected frequency and magnitude of peak streamflows observed. Peak-flow frequency data are determined from a series of the highest instantaneous annual peak discharges for the period of record at a streamgage. The probability that a peak will occur at a given location in a given year is determined from the annual peak streamflow data and is known as annual exceedance probability (AEP) (Holmes and others, 2013).

Each peak streamflow value listed in table 1 is an instantaneous peak flow that can be expected to be equaled or exceeded on the average once every " $y$ " years, where " $y$ " is the recurrence interval. Similarly, each instantaneous peak flow has an " $x$ "-percent probability of exceedance in any given year, where " $x$ " is the exceedance probability, in percent. For example, the instantaneous peak flow corresponding to the 100 -year recurrence interval can be expected to be equaled or exceeded on average once every 100 years; similarly, an instantaneous peak flow corresponding to a 1-percent AEP will have a 1-percent chance of being equaled or exceeded in any given year (table 2). Changes in land use, construction of new dams, and changes in long-term precipitation patterns can cause the designated AEPs and recurrence intervals for floods of a given magnitude to change over time (USGS, 2019c).

The flood-frequency estimates for this report were made by using the expected moments algorithm (Cohn and others, 1997, 2001) in the USGS software package PeakFQ, version 7.2 (Flynn and others, 2006; Veilleux and others, 2014) (table 3). 
Table 1. Site information for selected streamgages along the Arkansas River and peak streamflow values for the May to June 2019 flood event.

[USGS, U.S. Geological Survey; ft³/s, cubic foot per second; Ark., Arkansas; Okla., Oklahoma; >, greater than; <, less than; L\&D, Lock and Dam]

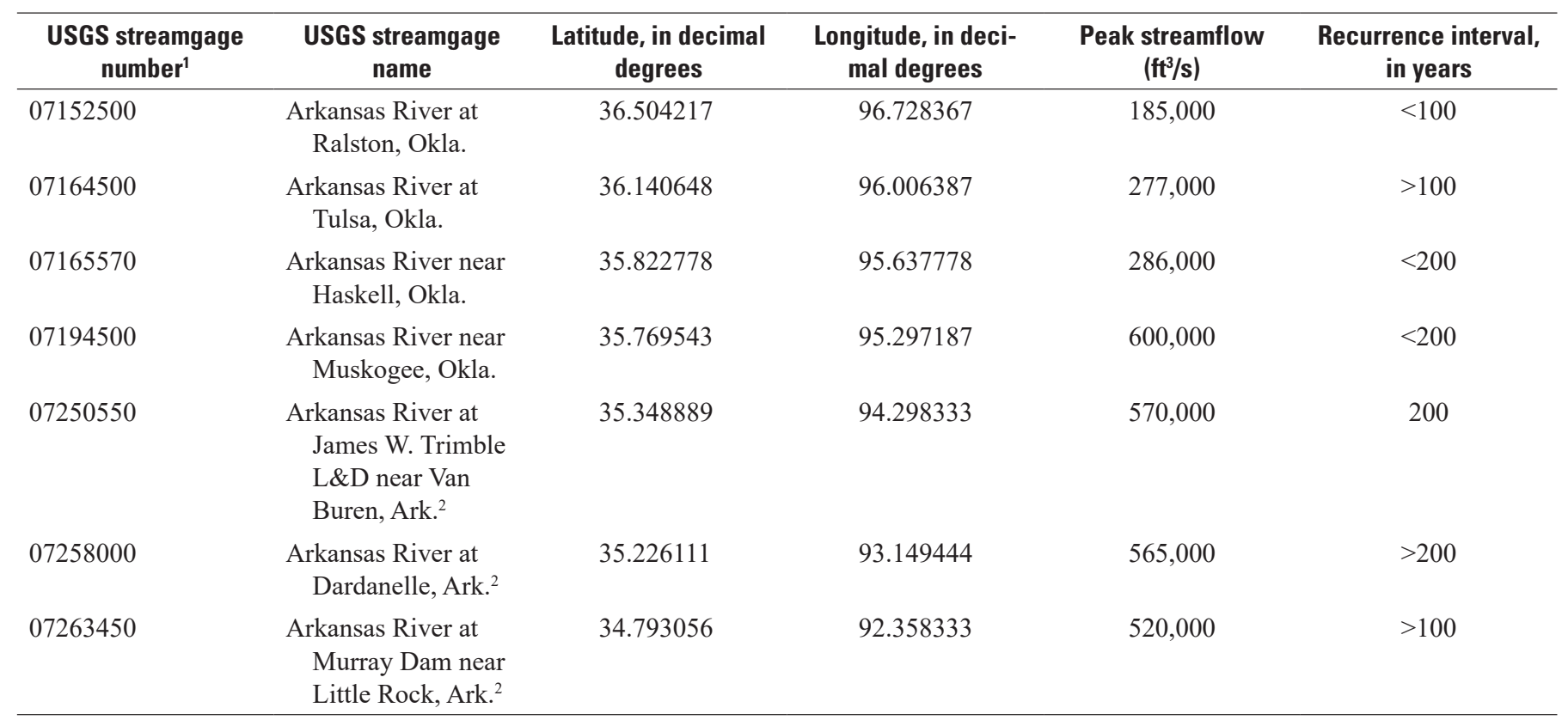

${ }^{1}$ Streamflow upstream from streamgage is regulated and, therefore, the estimated peak flows and confidence intervals were not weighted but represent the atsite flood-frequency analysis.

${ }^{2}$ Streamgage is operated by the U.S. Army Corps of Engineers, and data are quality assured and published by the USGS (2019b).

Table 2. Selected recurrence intervals and the associated annual exceedance probabilities.

\begin{tabular}{cc}
\hline $\begin{array}{c}\text { Recurrence interval } \\
\text { (years) }\end{array}$ & $\begin{array}{c}\text { Annual exceedance probability } \\
\text { (percent) }\end{array}$ \\
\hline 2 & 50 \\
5 & 20 \\
10 & 10 \\
25 & 4 \\
50 & 2 \\
100 & 1 \\
200 & 0.5 \\
500 & 0.2 \\
\hline
\end{tabular}


Table 3. Streamgage information related to calculation of annual exceedance probability for the May to June 2019 flood event along the Arkansas River in Oklahoma and Arkansas.

[AEP, annual exceedance probability; USGS, U.S. Geological Survey; ft, foot; $\mathrm{ft}^{3} / \mathrm{s}$, cubic foot per second]

\begin{tabular}{|c|c|c|c|c|c|c|c|c|c|}
\hline \multirow{3}{*}{$\begin{array}{c}\text { USGS } \\
\text { streamgage } \\
\text { number }\end{array}$} & \multirow{3}{*}{ USGS streamgage name } & \multirow{3}{*}{$\begin{array}{l}\text { Date of peak } \\
\text { streamflow }\end{array}$} & \multicolumn{4}{|c|}{ Peak streamflow for May to June 2019 flood } & \multirow{3}{*}{$\begin{array}{l}\text { Estimate, in } \\
\text { percent }\end{array}$} & \multirow{2}{*}{\multicolumn{2}{|c|}{$\begin{array}{c}\text { AEP for observed May to } \\
\text { June } 2019 \text { flood }\end{array}$}} \\
\hline & & & \multirow{2}{*}{$\begin{array}{l}\text { Peak gage } \\
\text { height (ft) }\end{array}$} & \multirow{2}{*}{$\begin{array}{l}\text { Peak stream- } \\
\text { flow }\left(\mathrm{ft}^{3} / \mathrm{s}\right)\end{array}$} & \multirow{2}{*}{$\begin{array}{l}\text { Rank of peak } \\
\text { streamflow in } \\
\text { record }\end{array}$} & \multirow{2}{*}{$\begin{array}{c}\text { Number of } \\
\text { annual peaks }\end{array}$} & & & \\
\hline & & & & & & & & $\begin{array}{l}\text { Lower, in } \\
\text { percent }\end{array}$ & $\begin{array}{l}\text { Upper, in } \\
\text { percent }\end{array}$ \\
\hline 07152500 & Arkansas River at Ralston, Okla. & $5 / 23 / 2019$ & 22.14 & 185,000 & 1 & 43 & 1.5 & 0.4 & 3.9 \\
\hline 07164500 & Arkansas River at Tulsa, Okla. & $5 / 29 / 2019$ & 23.51 & 277,000 & 2 & 55 & 0.7 & 1.3 & 5.8 \\
\hline 07165570 & Arkansas River near Haskell, Okla. & $5 / 29 / 2019$ & 24.24 & 286,000 & 1 & 47 & 0.7 & 0.4 & 3.9 \\
\hline 07194500 & Arkansas River near Muskogee, Okla. ${ }^{2}$ & $5 / 26 / 2019$ & 46.39 & 600,000 & 1 & 33 & 0.6 & 0.5 & 5.0 \\
\hline 07250550 & $\begin{array}{l}\text { Arkansas River at James W. Trimble } \\
\text { L\&D near Van Buren, Ark. }{ }^{3}\end{array}$ & $5 / 31 / 2019$ & 406.96 & 570,000 & 1 & 50 & 0.5 & 0.4 & 3.5 \\
\hline 07258000 & Arkansas River at Dardanelle, Ark. ${ }^{3}$ & $5 / 30 / 2019$ & 45.91 & 565,000 & 1 & 50 & 0.4 & 0.4 & 3.5 \\
\hline 07263450 & $\begin{array}{l}\text { Arkansas River at Murray Dam near } \\
\text { Little Rock, Ark. }{ }^{3}\end{array}$ & $6 / 4 / 2019$ & 259.75 & 520,000 & 1 & 50 & 0.8 & 0.4 & 3.5 \\
\hline
\end{tabular}

\begin{tabular}{|c|c|c|c|c|c|c|c|c|c|c|c|c|}
\hline \multirow{3}{*}{$\begin{array}{c}\text { USGS } \\
\text { streamgage } \\
\text { number }^{1}\end{array}$} & \multicolumn{3}{|c|}{ 2-percent AEP, 50-year recurrence } & \multicolumn{3}{|c|}{ 1-percent AEP, 100-year recurrence } & \multicolumn{3}{|c|}{ 0.5-percent AEP, 200-year recurrence } & \multicolumn{3}{|c|}{ 0.2-percent AEP, 500-year recurrence } \\
\hline & \multirow{2}{*}{ Estimate } & \multicolumn{2}{|c|}{$\begin{array}{c}\text { 95-percent confidence } \\
\text { interval }\end{array}$} & \multirow{2}{*}{ Estimate } & \multicolumn{2}{|c|}{$\begin{array}{l}\text { 95-percent confi- } \\
\text { dence interval }\end{array}$} & \multirow{2}{*}{ Estimate } & \multicolumn{2}{|c|}{$\begin{array}{c}\text { 95-percent confidence } \\
\text { interval }\end{array}$} & \multirow{2}{*}{ Estimate } & \multicolumn{2}{|c|}{$\begin{array}{c}\text { 95-percent confidence } \\
\text { interval }\end{array}$} \\
\hline & & $\begin{array}{l}\text { Lower } \\
\left(\mathrm{ft}^{3} / \mathrm{s}\right)\end{array}$ & $\begin{array}{l}\text { Upper } \\
\left(\mathrm{ft}^{3} / \mathrm{s}\right)\end{array}$ & & $\begin{array}{l}\text { Lower } \\
\left(\mathrm{ft}^{3} / \mathrm{s}\right)\end{array}$ & $\begin{array}{l}\text { Upper } \\
\left(\mathrm{ft}^{3} / \mathbf{s}\right)\end{array}$ & & $\begin{array}{l}\text { Lower } \\
\left(\mathrm{ft}^{3} / \mathrm{s}\right)\end{array}$ & Upper (ft $3 / \mathbf{s})$ & & $\begin{array}{l}\text { Lower } \\
\left(\mathrm{ft}^{3} / \mathrm{s}\right)\end{array}$ & Upper $\left(\mathrm{ft}^{3} / \mathrm{s}\right)$ \\
\hline 07152500 & 172,000 & 128,000 & 287,000 & 198,000 & 138,000 & 361,000 & 244,000 & 147,000 & 448,000 & 259,000 & 155,000 & 591,000 \\
\hline 07164500 & 206,000 & 149,000 & 387,000 & 252,000 & 173,000 & 544,000 & 302,000 & 196,000 & 755,000 & 377,000 & 226,000 & $1,150,000$ \\
\hline 07165570 & 217,000 & 159,000 & 424,000 & 261,000 & 183,000 & 601,000 & 310,000 & 207,000 & 847,000 & 382,000 & 237,000 & $1,320,000$ \\
\hline $07194500^{2}$ & 444,000 & 318,000 & 760,000 & 534,000 & 370,000 & 981,000 & 634,000 & 426,000 & $1,250,000$ & 781,000 & 503,000 & $1,680,000$ \\
\hline 07250550 & 442,000 & 358,000 & 692,000 & 503,000 & 395,000 & 880,000 & 567,000 & 431,000 & $1,110,000$ & 656,000 & 475,000 & $1,510,000$ \\
\hline 07258000 & 470,000 & 402,000 & 640,000 & 511,000 & 426,000 & 744,000 & 550,000 & 446,000 & 859,000 & 599,000 & 466,000 & $1,030,000$ \\
\hline 07263450 & 445,000 & 374,000 & 751,000 & 499,000 & 408,000 & 947,000 & 556,000 & 440,000 & $1,190,000$ & 637,000 & 482,000 & $1,620,000$ \\
\hline
\end{tabular}

${ }^{1}$ Streamflow upstream from streamgage is regulated; therefore, the estimated peak flows and confidence intervals were not weighted but represent the at-site flood-frequency analysis.

${ }^{2}$ Estimated peak flows and confidence intervals were weighted.

${ }^{3}$ Streamgage is operated by the U.S. Army Corps of Engineers, and data are quality assured and published by the USGS (2019b). 
Peak Streamflow and Stages at Selected Streamgages on the Arkansas River in Oklahoma and Arkansas

The methods used for computing peak-streamflow frequency are from a published report referred to as Bulletin 17C (England and others, 2019). Bulletin 17C is an update to Bulletin 17B (Interagency Advisory Committee on Water Data, 1982). Flood computation equations and algorithms in Bulletin $17 \mathrm{C}$ have been implemented into the PeakFQ program. The May 2019 peak streamflows were included in the PeakFQ analyses per guidance provided in USGS Office of Surface Water Technical Memorandum 2013.01 (USGS, 2012). Although Bulletin 17C states that guidelines do not apply to streamgages affected by reservoir regulation, with proper dataset handling, Bulletin 17C guidelines can be applied to produce reliable results at these streamgages (Advisory Committee on Water Information, 2002; USGS, 2012). Because the selected streamgages along the Arkansas River all have more than 80 percent of their drainage areas affected by reservoir regulation, the "at-site" skew was used to determine peak frequencies within PeakFQ. The only exception was the Arkansas River near Muskogee streamgage (07194500). The May 2019 flood produced an atypical upper-tail peak-flow record that required a special handling of the dataset (Sando and McCarthy, 2018). A weighted skew was used to calculate the flood frequencies instead of the station skew.

Six of the seven selected USGS streamgages recorded new peak streamflows in 2019, with the seventh gage (Arkansas River at Tulsa, Okla., streamgage 07164500) recording the second highest peak streamflow since regulation began (table 3). Ranks for peak streamflows are based on water year. ${ }^{1}$ The AEPs ranged from less than 1 to 1.5 percent for peak streamflows analyzed in this study. At the USGS streamgage Arkansas River near Muskogee, Okla. (07194500), a peak streamflow of 600,000 cubic feet per second was measured on May 26, 2019, corresponding to an AEP of 0.6 percent (fig. 6 ).

${ }^{1}$ The water year is the annual period from October 1 through September 30 and is designated by the year in which the period ends. For example, the 2019 water year is from October 1, 2018, through September 30, 2019.

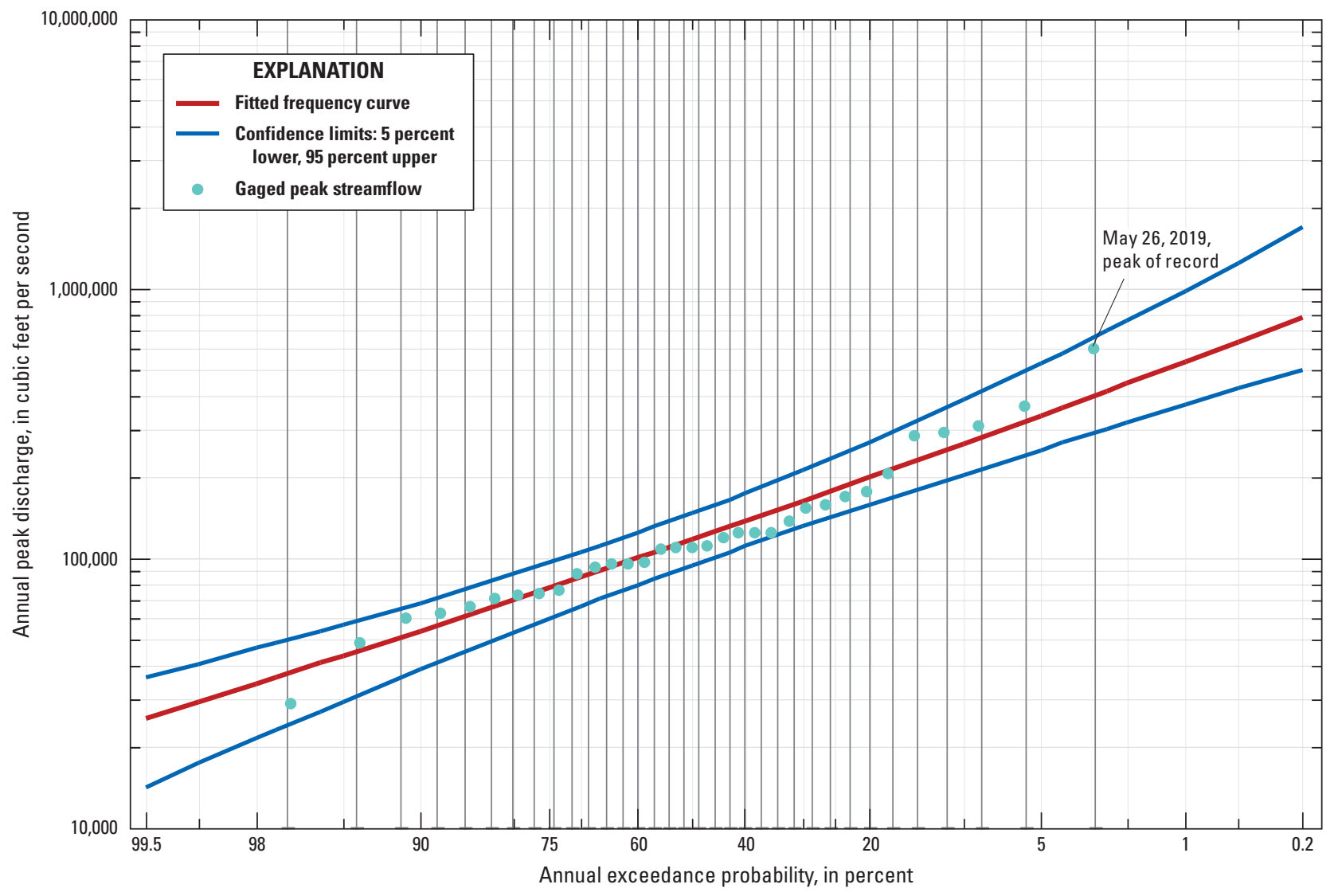

Figure 6. Flood-frequency curve for the annual peak streamflows at U.S. Geological Survey streamgage 07194500, Arkansas River near Muskogee, Oklahoma. 


\section{References Cited}

Advisory Committee on Water Information, 2002, Bulletin $17 \mathrm{~B}$, guidelines for determining flood frequencyFrequently asked questions, accessed April 30, 2007, at http://acwi.gov/hydrology/Frequency/B17bFAQ.html.

Cohn, T.A., Lane, W.L., and Baier, W.G., 1997, An algorithm for computing moments-based flood quantile estimates when historical flood information is available: Water Resources Research, v. 33, no. 9, p. 2089-2096. [Also available at https://doi.org/10.1029/97WR01640.]

Cohn, T.A., Lane, W.L., and Stedinger, J.R., 2001, Confidence intervals for expected moments algorithm flood quantile estimates: Water Resources Research, v. 37, no. 6, p. 1695-1706. [Also available at https://doi.org/10.1029/ 2001WR900016.]

Congressional Research Service, 2019, U.S. Geological Survey (USGS) Streamgaging Network-Overview and issues for Congress, accessed October 15, 2019, at https://fas.org/sgp/crs/misc/R45695.pdf.

England, J.F., Jr., Cohn, T.A., Faber, B.A., Stedinger, J.R., Thomas, W.O., Jr., Veilleux, A.G., Kiang, J.E., and Mason, R.R., Jr., 2019, Guidelines for determining flood flow frequency-Bulletin 17C (ver. 1.1, May 2019): U.S. Geological Survey Techniques and Methods, book 4, chap. B5, 148 p., accessed October 10, 2019, at https://doi.org/10.3133/tm4B5.

Flynn, K.M., Kirby, W.H., and Hummel, P.R., 2006, User's manual for program PeakFQ, annual flood-frequency analysis using Bulletin 17B guidelines: U.S. Geological Survey Techniques and Methods, book 4, chap. B4, 42 p. [Also available at https://pubs.usgs.gov/tm/2006/tm4b4/.]

Holmes, R.R., Jr., Wiche, G.J., Koenig, T.A., and Sando, S.K., 2013, Peak streamflows and runoff volumes for the Central United States, February through September, 2011: U.S. Geological Survey Professional Paper 1798-C, 60 p., accessed October 10, 2019, at https://pubs.usgs.gov/ $\mathrm{pp} / 1798 \mathrm{c} /$.

Interagency Advisory Committee on Water Data, 1982, Guidelines for determining flood-flow frequency: Bulletin 17B of the Hydrology Subcommittee, Office of Water Data Coordination, U.S. Geological Survey, Reston, Va., 183 p., https://water.usgs.gov/osw/bulletin17b/bulletin_17B.html.

Jackson, D., and Pittman, H., 2019, Throwback

Tulsa-Arkansas River unleashed fury in ' 86 flood:

Tulsa [Oklahoma] World, May 23, 2019, accessed

August 19, 2019, at https://www.tulsaworld.com/ news/local/throwback-tulsa-arkansas-river-unleashedfury-in-flood/article_fec26e4e-c9be-5eaa-ac0065c4d8e83056.html.
Mesonet, 2019, Oklahoma Climatological Survey weather data, accessed July 15, 2019, at http://www.mesonet.org/.

National Agricultural Statistics Service, 2016, CropScape, cropland day layers, 2010-15, accessed September 18, 2019, at https://nassgeodata.gmu.edu/CropScape/.

National Oceanographic and Atmospheric Administration [NOAA], 2019a, National Centers for Environmental Information, State of the climate-National climate report for May 2019, accessed September 4, 2019, at https://www.ncdc.noaa.gov/sotc/national/201905.

National Oceanographic and Atmospheric Administration [NOAA], 2019b, National Centers for Environmental Information, Climate data online-Daily summaries, accessed August 29, 2019, at https:/gis.ncdc.noaa.gov/ maps/ncei/summaries/daily.

National Oceanographic and Atmospheric Administration [NOAA], 2019c, National Centers for Environmental Information, Climate at a glanceRegional time series, accessed August 29, 2019, at https://www.ncdc.noaa.gov/cag/.

PBS News Hour, 2019, News wrap-Oklahoma flooding threatens to wash away homes, May 22, 2019, accessed October 15, 2019, at https://www.pbs.org/newshour/ show/news-wrap-oklahoma-flooding-threatens-to-washaway-homes.

PRISM Climate Group, 2019, PRISM climate data: Oregon State University, accessed September 3, 2019, at http://www.prism.oregonstate.edu/.

Sando, S.K., and McCarthy, P.M., 2018, Methods for peakflow frequency analysis and reporting for streamgages in or near Montana based on data through water year 2015: U.S. Geological Survey Scientific Investigations Report 2018-5046, 39 p., accessed October 10, 2019, at https://doi.org/10.3133/sir20185046.

Stanglin, D., and Hughes, T., 2019, Arkansas River bursts through levee north of Little Rock, triggering evacuations: USA Today, May 31, 2019, accessed June 17, 2019, at https:/www.usatoday.com/story/news/nation/2019/05/31/ arkansas-flood-levee-breach-prompts-evacuations-northlittle-rock/1297285001/.

Turnipseed, D.P., and Sauer, V.B., 2010, Discharge measurements at gaging stations: U.S. Geological Survey Techniques and Methods book 3, chap. A8, 87 p. accessed September 19, 2019, at https://pubs.usgs.gov/tm/tm3-a8/.

U.S. Army Corps of Engineers [USACE], 2010, Sand and gravel mining in Oklahoma waterways, guidelines for operators, accessed October 21, 2019, at https:/www.swt.usace.army.mil/portals/41/docs/missions/ regulatory/gravel1.pdf. 
U.S. Army Corps of Engineers [USACE], 2019, McClellanKerr Arkansas River Navigation System, accessed October 21, 2019, at https://www.swt.usace.army.mil/ Missions/Navigation/.

U.S. Geological Survey [USGS], 2012, Computation of annual exceedance probability (AEP) for characterization of observed flood peaks: U.S. Geological Survey Office of Surface Water Technical Memorandum 2013.01, accessed August 16, 2019, at https://water.usgs.gov/admin/memo/ SW/sw13.01.pdf.

U.S. Geological Survey [USGS], 2019a, WaterWatchCurrent water resources conditions, map of real-time streamflow compared to historical streamflow for the day of the year (United States): U.S. Geological Survey, accessed October 21, 2019, at https://waterwatch.usgs.gov.
U.S. Geological Survey [USGS], 2019b, USGS water data for the Nation: U.S. Geological Survey National Water Information System database, accessed October 15, 2019, at https://doi.org/10.5066/F7P55KJN.

U.S. Geological Survey [USGS], 2019c, Floods and recurrence intervals, accessed October 15, 2019, at https://www.usgs.gov/special-topic/water-science-school/ science/floods-and-recurrence-intervals?qt-science_center objects $=0 \#$ qt-science_center_objects.

Veilleux, A.G., Cohn, T.A., Flynn, K.M., Mason, R.R., Jr., and Hummel, P.R., 2014, Estimating magnitude and frequency of floods using the PeakFQ 7.0 program: U.S. Geological Survey Fact Sheet 2013-3108, 2 p., accessed October 10, 2019, at https://doi.org/10.3133/fs20133108. 
For more information about this publication, contact

Director, Oklahoma-Texas Water Science Center

U.S. Geological Survey

1505 Ferguson Lane

Austin, Texas 78754-4501

(512) 927-3500

For additional information visit

https://www.usgs.gov/centers/ok-water/

Publishing support provided by

Lafayette Publishing Service Center 

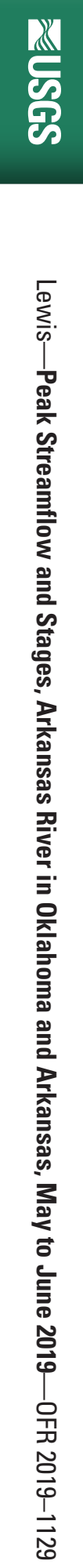